\title{
Quality Changes and Microbial Load of Marinated Tilapia (Oreochromis niloticus) Stored at Refrigeration Temperature
}

\section{Omaima M. Ahmed ${ }^{1}$, Hesham F. Amin ${ }^{1}$, Abdel-hamied M. Rasmey ${ }^{2}$, and Mofeeda Tolpa ${ }^{1}$}

${ }^{1}$ Department of Fish Processing and Technology, College of Fish Resources, Suez University, Suez, Egypt.

${ }^{2}$ Department of Botany and Microbiology, College of Science, Suez University, Suez, Egypt.

\begin{abstract}
Tilapia is the main species farmed commercially in Egypt and is the most common for marketing as fresh fish. However, the usage of tilapia in marinade production is not common in Egyptian culture. The current investigation was aimed to produce tilapia (Oreochromis niloticus) marinade using different acetic acid concentrations with different methods, to determine its bacterial load and best sensory quality during storage at $4^{\circ} \mathrm{C}$. The fish processing were headed, gutted, filleted, marinated and stored at $4^{\circ} \mathrm{C}$ until the end point, which was assessed by $\mathrm{pH}$ measuring, sensory, and microbiological analyses. Warm marinated was performed using solutions containing $2,3 \%$ acetic acid and $3 \% \mathrm{NaCl}$ then transferred into plastic jars, covered with $3 \%$ gelatin. Higher concentrations of acetic acid (5\%) and $\mathrm{NaCl}(6 \%)$ were used for cold marinating process for 30 days then transferred into packaging solution of $2.5 \%$ acetic acid and $3 \%$ $\mathrm{NaCl}$. Bacterial load has increased after 7 days with warm marinated fillets with best sensory scores in the first 3 days using 3\% acetic acid solution, and best sensory scores in the first 7 days with $2 \%$ acetic acid. For cold marinated fillets, load of bacteria was reduced after 3 days from application of marinating solution until to the end of marinating process and after application of packaging solution with $2.5 \%$ acetic acid. The best sensory scores of cold marinated fillets were lower than the ones belong to warm marinated process. There is no significant change ( $\mathrm{p}>0: 05)$ in $\mathrm{pH}$ values during storage. KEYWORDS: Fish; marinated tilapia; Oreochromis niloticus; marinating, bacterial load
\end{abstract}




\section{Introduction}

Egypt has been the second largest producer of tilapia in the world for many years, with an enormous potential for further development in tilapia industry (MacMillan, 2014). One of the most common value added product is processing of fillet. Today, an important component of the growing tilapia industry is the proliferation of various product forms.

Due to the increasing consumer demand for fish products with prolonged shelf-life, many researches have focused on preservation techniques to control bacterial growth for safety purposes or for extending the shelf-life of the products (Sallam, 2007). Marinades are fish products consisting of fresh, frozen, salted fish or portions of fish processed by treatment with edible acids and salt and put up in brines, sauces, creams or oil (Meyer, 1965). Marinades are semipreserves; acid, usually acetic acid and salt are added to the fish to retard the action of bacteria and enzymes resulting in a product with a characteristic flavor and an extended but limited shelf life (McLay, 1972). The aim of Marinating is not only to prevent microorganism growth, but also is used to tenderize or to change taste, textural and structural properties of raw material. Initial quality of raw materials, considering their freshness, microbiological load and physical damage, is an important factor which influences the quality

of the end product (Fuselli et al, 1994). Keeping qualities depend largely upon storage temperatures. Marinades stored at cooler temperatures $\left(4-6^{\circ} \mathrm{C}\right)$ keep a long time.

Tilapia in aquaculture is an important and common species in Egypt. It is generally consumed as fresh, or minimally processed, but usage of marinated Tilapia is not common in Egypt. In this study, the usage of Tilapia in marinade production was tried using different acetic acid concentrations with different methods. The aim of the study was to produce Tilapia marinade, to determine its microbiological and best sensory quality during storage at $4^{\circ} \mathrm{C}$.

\section{Materials and Methods}

Raw material

Fresh cultured tilapia fish (Oreochromis niloticus) was purchased in November 2014 from local market, Suez, Egypt. Total 10 $\mathrm{kg}$ fish were obtained and transferred to the laboratory in an iced box with crushed ice. Fish were headed, filleted, skinned, washed and marinated. Samples (10 g) were taken from skinned fish fillet before and during the marinating process for microbiological analysis.

Marinating process

Productions of cold and warm marinated tilapia fillets were carried 
as shown in (Fig.1). Marinating was done by immersing the fish fillets into solutions containing acetic acid and $\mathrm{NaCl}$. These solutions were selected for the present study.

Solution A: 2\% acetic acid, 3\%

$\mathrm{NaCl}, 3 \%$ gelatin.

Solution B: 3\% acetic acid, 3\%

$\mathrm{NaCl}, 3 \%$ gelatin.

Solution C: $5 \%$ acetic acid, $6 \%$

$\mathrm{NaCl}$.

Solution D: $2.5 \%$ acetic acid, $3 \%$

$\mathrm{NaCl}$.

Solution A, and B were used in warm marinating, fish fillets were kept in these solutions during all the process. Solution $\mathrm{C}$ used as initial solution during maturation in cold marinating process then changed to solution $\mathrm{D}$ as a packaging solution. Warm marinated fillets were kept in plastic jar containers with addition of gelatin. (Karim, and Bhat, 2009). (Fig. 1) (AOAC, 1995).

The ratio of fish to solution was 1:1. Immersing process was performed at ambient temperature $\left(25^{\circ} \mathrm{C}\right)$. Packed fish were stored at $4{ }^{\circ} \mathrm{C}$ and analyzed at different time intervals to determine the microbiological and sensory quality of the product (Goko€glu et al., 2004).

Analysis

Before every analysis, two fish fillets from the jar were randomly taken and all the fish were pooled. Then the fish flesh were homogenized and analyzed for the following parameters: $\mathrm{pH}$ measurement
Fish samples were homogenized with distilled water at ratio of 1:9 $(\mathrm{W} / \mathrm{V})$ in a blender. The $\mathrm{pH}$ was measured by dipping the $\mathrm{pH}$ electrode into a mixture of homogenized sample according to AOAC (1995).

Sensory analyses:

In Sensory evaluation studies, marinated fish were assessed on the basis of appearance, odour, taste and texture characteristics using a 5-point scale. A score of 5.0, 4.0, 3.0, 2.0 and 1.0 indicated excellent, very good, good, fair and poor quality, respectively. Sensory evaluations were conducted using five experienced panelists (Meilgoard et al., 2007).

Bacteriological sampling and analysis:

Sampling was analyzed for microbiological investigations for 54 days of warm marinated fish with solution A, and B. Before starting marinating, fishes were processed into fillets and microbiological loads were tested and represented by sample zero. Fillets were steamed (steamed sample), marinated and stored at refrigeration temperature $\left(4^{\circ} \mathrm{C}\right)$. Samples were taken at day 1, 2, 3, 7 , and 54 day intervals. Whereas sampling extended for up to 42 days with cold marinated fish with solutions $\mathrm{C}$ and D.

For all microbiological counts, $\mathbf{1 0} \mathbf{g}$ samples were homogenized in $\mathbf{9 0}$ $\mathrm{ml} 0.1 \%$ peptone water $(\mathrm{LAB} \mathrm{M})$. 
From this $10^{-1}$ dilution, other decimal dilutions were prepared. Total viable count was determined by the spread plate method, using Plate Count Agar (PCA) (Difco, 0479-17) as the medium. Total coliform was enumerated by spread-plating on to Brilliant Green agar (BG), Escherichia coli on Sorbitol MacKoncy (SMAC), and Salmonella sp. on XLD. Plates were incubated at $37^{\circ} \mathrm{C}$ for 24 hours and colony forming units (CFU) were counted (Santo et al, 2008). Readings obtained with 30 to 300 colonies on a plate were used to calculate bacterial population numbers, recorded as CFU per gram of sample (Al-Harbi and Uddin, 2005). Three to five representatives of each colony type were then streaked on additional Tryptcase Soy Agar slants (TSA). The isolates were then subjected to biochemical tests (citrate, Methyl red, VogesProskauer, indole, $\mathrm{H}_{2} \mathrm{~S}$ production, and triple sugar iron) for identification.

\section{Statistical Analysis}

Data were treated by analysis of variance using SPSS (2006). Significance was established at $\mathrm{p}<$ 0.05. Means and standard deviations were estimated.

\section{Results and Discussion}

The microbiological determinations were performed to assess the procedures related to the processing of the tilapia marinated fillets. Results of the quantitative estimation of aerobic bacteria in warm marinated fish using $2 \%$ acetic acid (solution A) and 3\% acetic acid (solution B) are shown in Table 1. Steam temperature decreased slightly the initial bacterial counts in zero sample for both acetic acid concentrations from $6 \log \mathrm{CFU} / \mathrm{g}$ to $5.5 \log \mathrm{CFU} / \mathrm{g}$. The salting and marinating processes reduced the total bacterial viable count to $4.6 \log \mathrm{CFU} / \mathrm{g}$ in two days with an agreement with Furutani et al (2013). Results fluctuated to 5.9, 4.6, and $5.5 \log \mathrm{CFU} / \mathrm{g}$ for samples 1,2 , and 3 , respectively in the first 3 days. Results agreed also with $\mathbf{K i n}$ et al (2011) indicate that the use of acetate salts minimizing bacterial counts of fish fillets during the first 7 days from application $(\mathrm{P}<0.05)$.

The initial quality of fish used in this study was good as indicated by a low initial number of suspected bacteria. Salmonella, coliform, and E. coli were not detected during the first days of storage. No defined result was found on selective plates of SMAC, XLD, and BG with both methods for up to 3 days (estimated less than $2 \log \mathrm{CFU} / \mathrm{g}$ ). It was reported that sorbic, benzoic, gluconic, acitric acids, and acetic acid in this case, inhibited the growth of bacteria (Poligne and Collignan, 2000; Cadun et al, 2005; Bjo"rkroth, 2005). Total bacterial count increased after day 7 , and by the end of storage period (54 days) increased more to reach 8.9, 8, 8.8, and 8.6 Log CFU/g on SMAC, PCA, XLD, and BG in 
marinated fish using solution A. In marinated fish using Solution B, coliform count $(8.1 \log \mathrm{CFU} / \mathrm{g})$ on $\mathrm{BG}$ was less than that $(8.6 \mathrm{log}$ $\mathrm{CFU} / \mathrm{g}$ ) in solution A, E.coli, and Salmonella count were the same, and a slight increase was detected in total bacterial count on PCA (8.1 $\log \mathrm{CFU} / \mathrm{g}$ ). Özogul et al (2009) had reported similar results with reduction of total bacterial count after application of warm marinating with $4 \%$ acetic acid solution to be decreased to $3.2 \operatorname{logs}$ $\mathrm{CFU} / \mathrm{g}$. After that, total bacterial count started to increase to $4.3 \mathrm{log}$ $\mathrm{CFU} / \mathrm{g}$ at the end of storage period. Increased bacterial count after 7 days may also be the result of lactic acid bacteria growth that added to the total count in low acid marinated fish (Silva and White 1994).

Cold marinating was another process used to marinate tilapia without any steaming. The results of the microbiological tests of the cold marinated tilapia fillets using solutions $\mathrm{C}$, and $\mathrm{D}$ conserved under refrigeration $\left(4^{\circ} \mathrm{C}\right)$ are shown in Table 2. Bacterial load started with high count reached up to $7 \mathrm{log} / \mathrm{g}$ CFU and a little higher on SMAC, PCA, XLD, and BG (Table.2). Complete reduction after 2 days of application of 5\% acetic acid solution, as bacterial count reduced and estimated to be less than $2 \log$ $\mathrm{CFU} / \mathrm{g}$ on SMAC, XLD, and BG. As can be seen, all the results obtained for E.coli, total coliform, and Salmonella sp. were within the acceptance limits for consumption after 2 days from marinating. On the other hand, tiny anaerobic bacteria grew on PCA from the $3^{\text {rd }}$ day until the end of storage period. It was reported that the marinating process reduced the number of Enterobacteriacae and $\mathrm{H}_{2} \mathrm{~S}$ producing bacteria within 3 days, while the total viable count and the lactic acid bacteria slightly increased during the storage due to lower $\mathrm{pH}$ that favor the growth of lactic acid bacteria (Giuffrida et al, 2007).

Suspected colonies were selected from SMAC, XLD, and BG in warm and cold marinating processes were tested biochemically on Citrate, Methyl red, Vogus Proskour, and triple sugar iron slants. Results were positive for $E$ coli and negative for Salmonella sp. The $\mathrm{pH}$ in fresh fish flesh is almost neutral. In the post-mortem period, decomposition of nitrogenous compounds leads to an increase in $\mathrm{pH}$ in the fish flesh (Shenderyuk \& Bykowski, 1989). The increase in $\mathrm{pH}$ indicates the loss of quality. Marinades have a low $\mathrm{pH}$ due to acetic acid content. During the storage of marinades, lactic acid bacteria can grow and cause the amino acids to degrade. Thus, the formation of carbon dioxide and other decarboxylation products is observed. These products bind 
acetic acid and the $\mathrm{pH}$ of marinade rises (Shenderyuk \& Bykowski, 1989). $\mathrm{pH}$ levels of samples marinated with $5 \%$ acetic acid solution started from $4.9 \pm 1$ for the first 9 days then rose after 38 and 42 days to be 5.5, and 6.2. This increase might be explained because of changing the marinating solution to use packaging solution with $2.5 \%$ acetic acid (solution D). $\mathrm{pH}$ value in raw fish flesh was found 6.5. Kristinsson et al (2005) found a $\mathrm{pH}$ value of 6.5 in Tilapia too. The $\mathrm{pH}$ value in tilapia found by Santo et al. (2008) and Abelti (2013) were 6.4, 6.1 respectively. There was a significant difference $(\mathrm{p}<0: 05)$ in $\mathrm{pH}$ between samples marinated in 2 and $3 \%$, acetic acid solutions and these did not change significantly ( $\mathrm{p}>0: 05)$ during storage (Fig. 3). Other researchers reported insignificant changes in $\mathrm{pH}$ levels of marinated fish. Poligne and Collignan (2000) found that the $\mathrm{pH}$ levels of anchovies pickled with acetic acid increased from 3.90 to 4.21 after $20 \mathrm{~d}$ of storage and then remained constant until the end of the storage. Gokofglu et al.
(2004) found that $\mathrm{pH}$ of marinated sardine in 2 and $4 \%$ acetic acid solutions did not change significantly (p >0:05) during storage for up to 150 days.

Sensory scores of marinated Tilapia significantly decreased $(\mathrm{p}<0: 05)$ throughout the storage especially except marinated fish using 2\% acetic acid solution. Sensory scores of Tilapia marinated with acetic acid solution of $3 \%$ were significantly higher $(\mathrm{p}<0: 05)$ than those found in Tilapia marinated with acetic acid of $2 \%$ and $5 \%$ (Fig.2). The samples had "very good" and its best quality for up to 54 days for $2 \%$ acetic acid, and first 3 days for $3 \%$ and $5 \%$ acetic acid solutions and that was agreed with (GokoEglu et al, 2004).

\section{Conclusion}

It was concluded that, the results showed that warm marinated tilapia could be consumed safely throughout the first week from storage period while the cold marinated tilapia (Oreochromis niloticus ) fillet could be stored safely for up to 42 days at $4{ }^{\circ} \mathrm{C}$. 


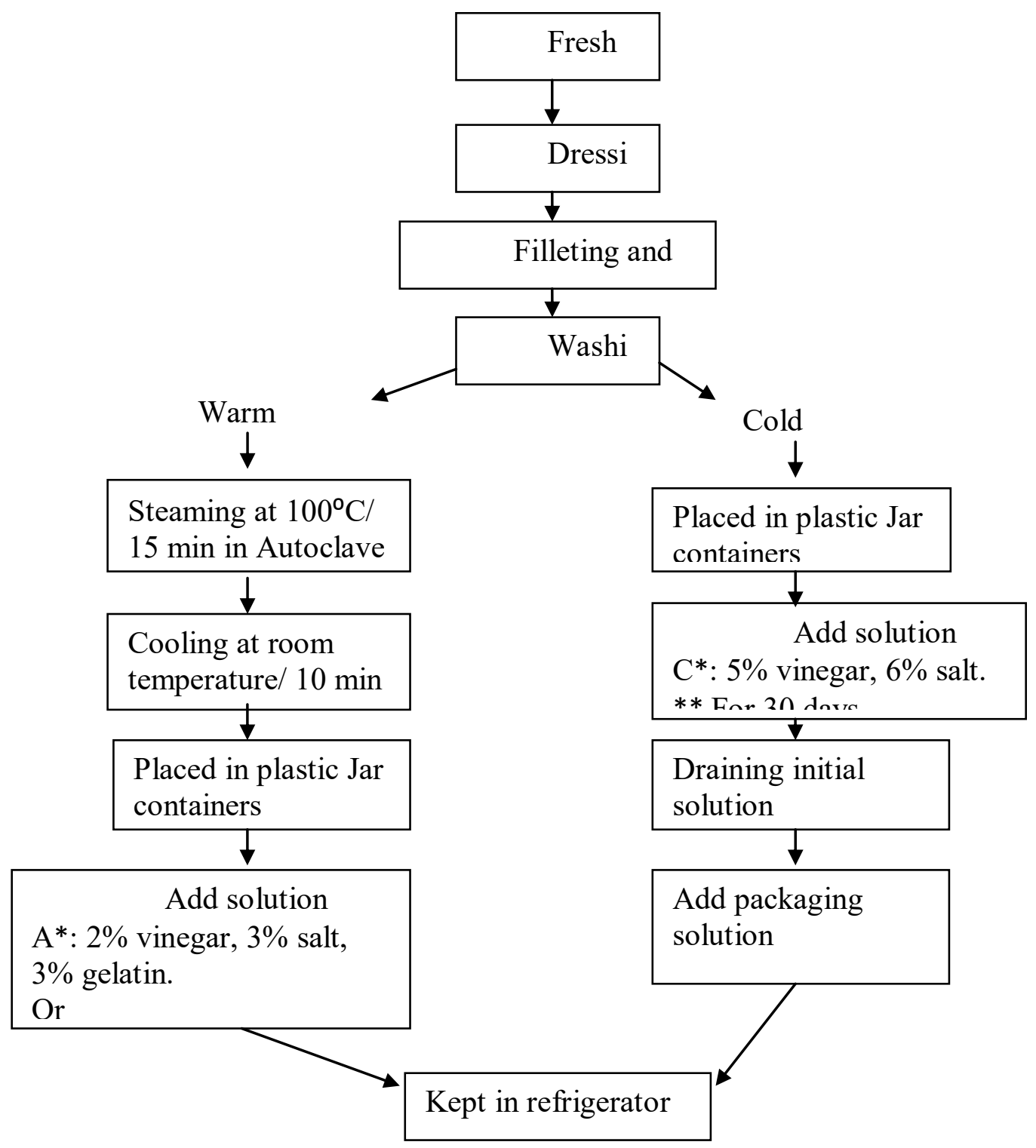

Fig 1: |Outlines of cold and warm marinated Tilapia (Oreochromis niloticus) fillets.

* Fish to solution ratio, 1:1 ** Until maturation 


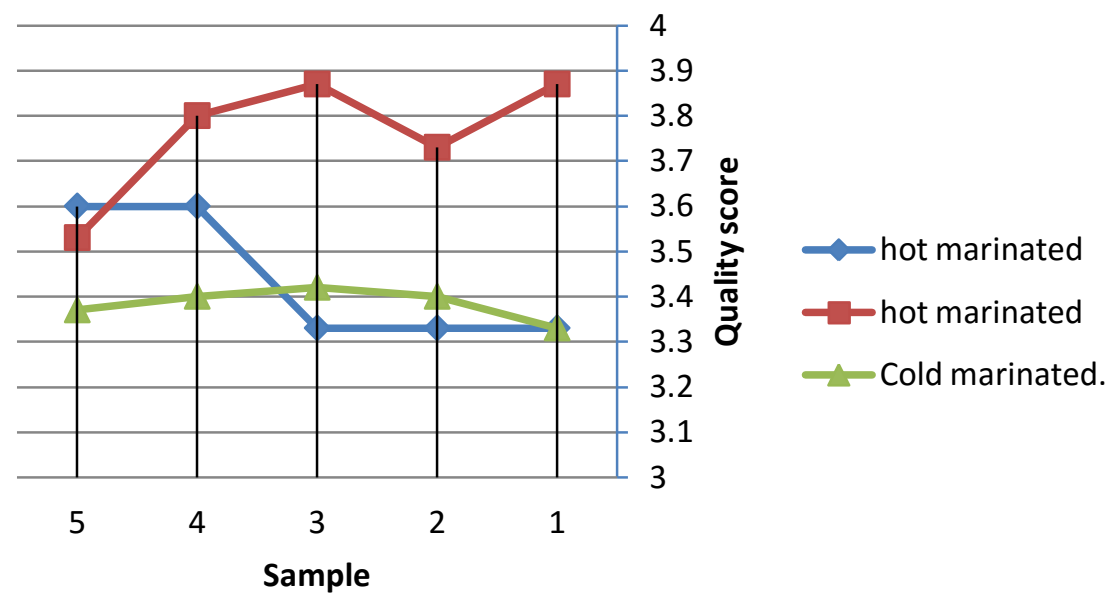

Fig 2: Sensory scores of marinated Tilapia (Oreochromis niloticus) during storage at $4^{\circ} \mathrm{C}$.

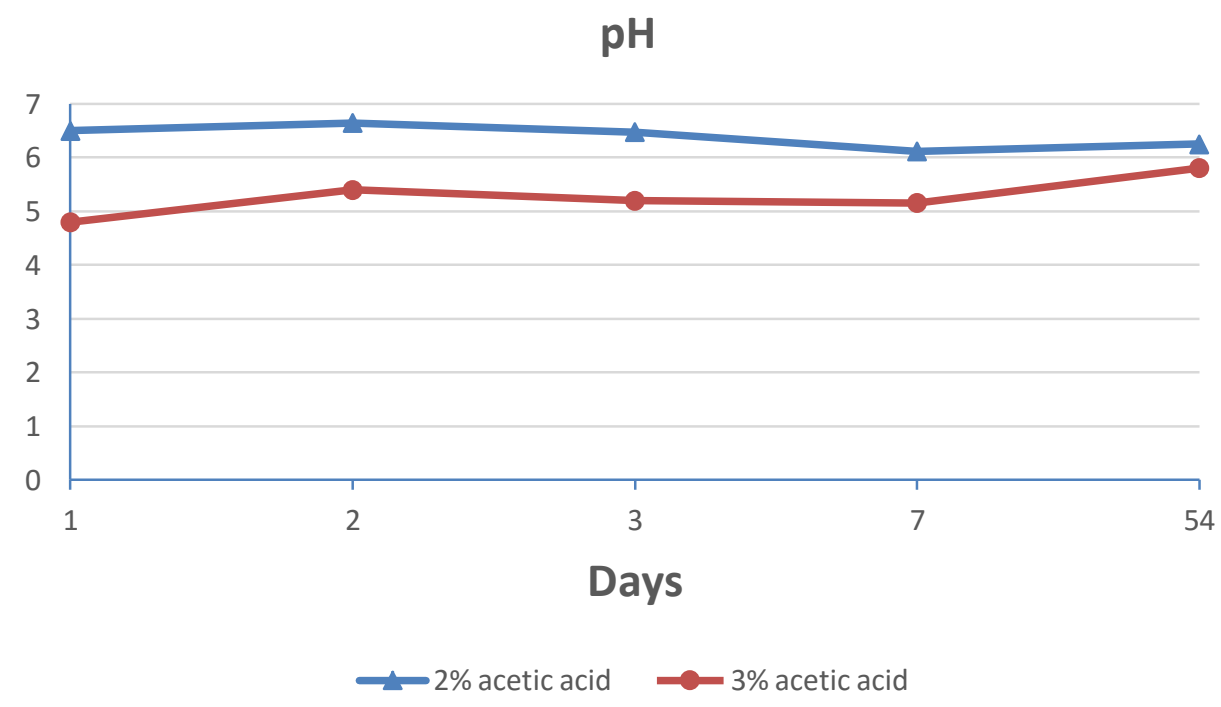

Fig 3: $p H$ values of marinated Tilapia (Oreochromis niloticus) during storage at $4 C$. 
Table 1: Bacterial load (CFU/g) of marinated fish using 2\% acetic acid (solution $\mathrm{A}$ ), $3 \%$ acetic acid (solution $\mathrm{B}$ ).

\begin{tabular}{|c|c|c|c|c|c|c|c|c|c|}
\hline & \multicolumn{4}{|c|}{ WARM MARINATING USING 2\% } & \multicolumn{3}{c|}{ WARM MARINATING USING 3\% } \\
ACETIC ACID & \multicolumn{4}{c|}{ Log (CFU/g) } \\
\hline $\begin{array}{c}\text { DA } \\
\text { YS }\end{array}$ & $\begin{array}{c}\text { sam } \\
\text { ple }\end{array}$ & \multicolumn{3}{|c|}{ Log (CFU/g) } & \multicolumn{3}{c|}{} \\
\hline & & SMAC & $\begin{array}{c}\text { PC } \\
\text { A }\end{array}$ & XLD & BG & SMAC & PCA & XLD & BG \\
\hline $\mathbf{1}$ & zero & $<2$ EST & 6 & $<2$ EST & $<2$ EST & $<2$ EST & 6 & $<2$ EST & $<2$ EST \\
\hline $\mathbf{1}$ & $\begin{array}{c}\text { stea } \\
\text { med }\end{array}$ & $<2$ EST & 5.5 & $<2$ EST & $<2$ EST & $<2$ EST & 5.5 & $<2$ EST & $<2$ EST \\
\hline $\mathbf{1}$ & 1 & $<2$ EST & 5.9 & $<2$ EST & $<2$ EST & $<2$ EST & 5.9 & $<2$ EST & $<2$ EST \\
\hline $\mathbf{2}$ & 2 & $<2$ EST & 4.6 & $<2$ EST & $<2$ EST & $<2$ EST & 4.6 & $<2$ EST & $<2$ EST \\
\hline $\mathbf{3}$ & 3 & $<2$ EST & 5.5 & $<2$ EST & $<2$ EST & $<2$ EST & 5.5 & $<2$ EST & $<2$ EST \\
\hline $\mathbf{7}$ & 4 & 8.6 & 6.8 & 7.9 & 8.0 & 8.1 & 6.4 & 8.1 & 7.1 \\
\hline $\mathbf{5 4}$ & 5 & 8.9 & 7.5 & 8.8 & 8.6 & 8.9 & 8.4 & 8.8 & 8.1 \\
\hline
\end{tabular}

Table 2: Bacterial load (CFU/g) of cold marinated fish using 5\% acetic acid (solution $\mathrm{C}$ ) and $2.5 \%$ acetic acid (solution $\mathrm{C}$ ) .

\begin{tabular}{|c|c|c|c|c|c|}
\hline DAYS & SAMPLE & \multicolumn{4}{|c|}{ LOG (CFU/ SAMPLE UNIT) } \\
\hline & & SMAC & PCA & XLD & BG \\
\hline $\mathbf{1}$ & zero & 7.2 & 7.4 & 7.3 & 7.0 \\
\hline $\mathbf{1}$ & 1 & 7.4 & 8.5 & 8.5 & 7.5 \\
\hline $\mathbf{2}$ & 2 & 8.5 & 8.7 & 8.8 & 8.3 \\
\hline $\mathbf{4}$ & 3 & $<2 \mathrm{EST}$ & 7.5 anaerobic & $<2$ EST & $<2$ EST \\
\hline $\mathbf{7}$ & 4 & $<2 \mathrm{EST}$ & 7.7 anaerobic & $<2 \mathrm{EST}$ & $<2 \mathrm{EST}$ \\
\hline $\mathbf{9}$ & 5 & $<2 \mathrm{EST}$ & 8.4 anaerobic & $<2$ EST & $<2$ EST \\
\hline $\mathbf{3 8}$ & 6 & $<2 \mathrm{EST}$ & 8.9 anaerobic & $<2$ EST & $<2$ EST \\
\hline $\mathbf{4 2}$ & 7 ( solution D) & $<2$ EST & 8.3 anaerobic & $<2$ EST & $<2$ EST \\
\hline
\end{tabular}

\section{References}

Abelti L.A.(2013). Microbiological and Chemical Changes of Nile Tilapia (Oreochromis niloticus L.) Fillet during Ice Storage: Effect of Age and Sex. Advance Journal of Food Science and Technology, 5(10), 1260-1265.
Al-Harbi A., UddinN. (2005). Bacterial diversity of tilapia (Oreochromis niloticus) cultured in brackish water in Saudi Arabia. Journal of Aquaculture, 250, 566572.

AOAC, Association of Official Analytical Chemists. (1995). 
Official Methods of Analysis, Association of Analytical Chemists. Washington, DC.

$\begin{array}{lll}\text { Björkroth } & \text { J. } & \text { (2005). } \\ \text { Microbiological } & \text { ecology of }\end{array}$ marinated meat products. Journal of Meat Science 70, 477-480.

Cadun A., Cakli S. and Kisla D. (2005). A study of marination of deepwater pink shrimp (Parapenaeus longirostris, Lucas, 1846) and its shelf life. Journal of Food Chemistry 90, 53-59.

Furutani A., Matsubara H., Ishikawa S., Satomi M. (2013).Behavior of histamineproducing bacteria in shimesaba, raw mackerel salted and marinated in vinegar during processing and storage at various temperatures. Journal of Fisheries Science, 79(4), 725-733.

Fuselli, S. R., Casales, M. R., Fritz. R., Yeannes, M. I. (1994). Microbiology of the marination process used in anchovy (Engraulis anchiota) production. Lebensm. Wiss u.-Technol, 27, 214-218.

Giuffrida A., Ziino G., Orlando G. and Panebianco A. (2007). Hygienic evaluation of marinated sea bass and challenge test for Listeria monocytogenes. Journal of Veterinary Research Communications 31(1), 369-371.

Goko€glu N., Ceng E., Yerl_lkaya P. (2004). Determination of the shelf life of marinated sardine (Sardina pilchardus) stored at $4{ }^{\circ} \mathrm{C}$. Journal of Food Control, 15,1-4.
Karim A., Bhat R. (2009). Fish gelatin: properties, challenges, and prospects as an alternative to mammalian gelatins. Food Hydrocolloids 23:563-576.

Kin S., M. Schilling W., Smith B.S,. Silva JL, Kim T., Pham AJ, and Campano SG. (2011).

Potassium Acetate and Potassium

Lactate Enhance the

Microbiological and Physical

Properties of Marinated Catfish

Fillets. Journal of Food Science 76

(4):242-250.

Kristinsson H., Mony S., Petty

H. (2005). Properties of tilapia carboxy- and oxyhemoglobin at postmortem $\mathrm{pH}$. Journal of agricultural and food chemistry, 53(9), 3643-3649.

MacMillan S. (2014). Egyptian aquaculture: Farming tilapia, mullet and carp in the Nile Delta. International Livestock Research Institute.

McLay, R. (1972). Marinades. Torry Advisory Note No: 56. Ministry of Agriculture, Fisheries and Food, Torry Research Station. Aberdeen.

Meilgaard, M., Civille, G.V.\&Carr,B.T. (2007). Sensory Evaluation Techniques. $4^{\text {th }}$ ed. CRC press, BocaRaton, FL.

Meyer, V. (1965). Marinades. In G. Borgstrom (Ed.), Fish as food (Vol. 3, Part 1). New York: Academic Press.

Nalan G., Emel C., Pinar Y. (2002). Determination of the shelf life of marinated sardine (Sardina 
pilchardus) stored at $4{ }^{\circ} \mathrm{C}$. Journal of Food Control, 15, 1-4.

O“zogul Y., Kuley E., O“zogul F.(2009). Quality Changes of Marinated Tench (Tinca tinca) during Refrigerated Storage. Journal of Food Sci Tech Int, 15(5):513-521.

Poligne, I., \&Collignan, A. (2000). Quick marination of anchovies (Engraulisen chrasicolus) using acetic and gluconic acids. Quality and stability of the end product. Lebensm.-Wis. u.-Technol, 33, 202-209.

Sallam Kh. (2007). Antimicrobial and antioxidant effects of sodium acetate, sodium lactate, and sodium citrate in refrigerated sliced salmon. Journal of Food Control 18: 566575.
Santo M.L., Vivian V., Mirapalheta T., Carbonera N., Coelho G., Damian C. (2008). Chemical, physical and microbiological changes in tilapia (Oreochromis niloticus) during marination. Alimentos e Nutrição, 18(1), 1-4.

Shenderyuk, V. I., \&Bykowski, P. J. (1989). Salting and marinating of fish. In Z. E. Sikorski (Ed.), Seafood: resources, nutritional composition and preservation. Boca Raton, Florida: CRC Press, Inc.

Silva JL, White TD. (1994).

Bacteriological and color changes in modified atmosphere-packaged refrigerated channel catfish. Journal of Food Protection 57:715-9.

SPSS (2006): SPSS 15.0 for window evaluation version. Statistical Package for Social Sciences. SPSS Inc.

\section{تغيرات الجودة و الحمل الميكروبى الخاص بأسماك البلطى المخللة و المخزنة فى درجة التبريد}

البلطى من أهم الأنواع المستزرعة تجاريا في مصر وهي الأكثر شيوعا للتسويق كما الأسماك

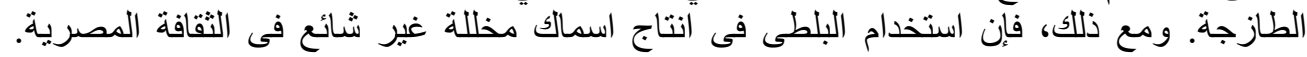

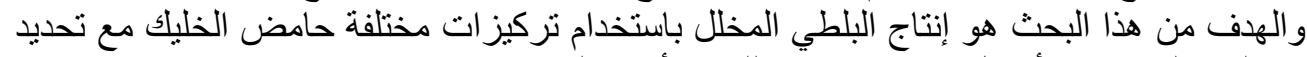

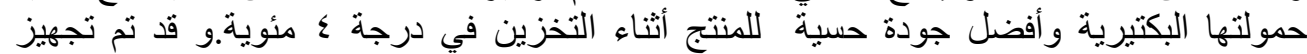

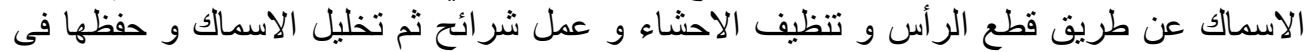

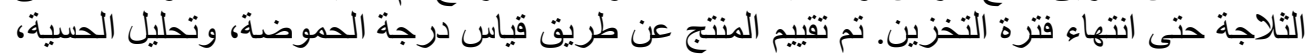

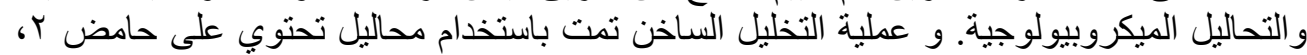

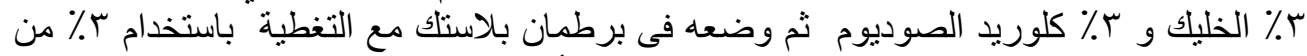

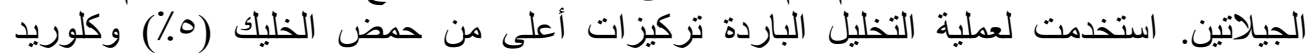

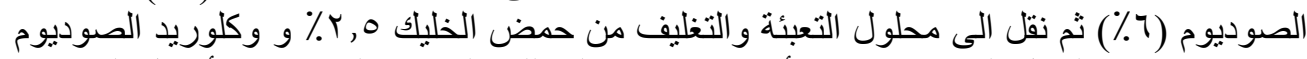

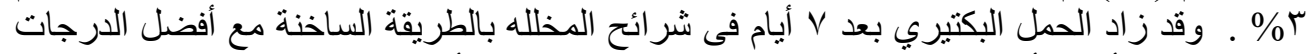

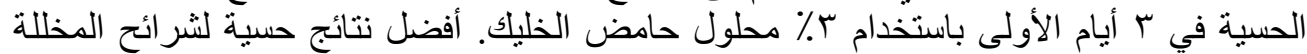

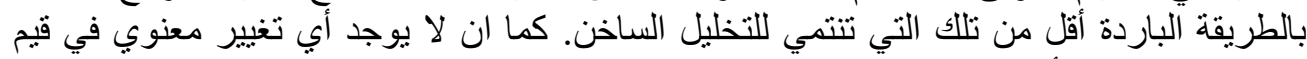
الرقم الهيدروجيني أثناء التخزين.(p>00:05) 